\title{
Risk Factors for Mortality of COVID-19 Patients
}

\section{Ouail Ouchetto $^{1,2}$, Asmaa Drissi Bourhanbour ${ }^{3,4}$}

${ }^{1}$ LIMSAD-FSAC, Hassan II University of Casablanca, 20000 Casablanca, Morocco

${ }^{2}$ FSJES-AC, Hassan II University of Casablanca, 20000 Casablanca, Morocco

${ }^{3}$ Laboratory of Immunology, Ibn Rochd University Hospital Center, Casablanca, Morocco

${ }^{4}$ Faculty of Medicine and Pharmacy, Hassan II University of Casablanca, Casablanca, Morocco

Correspondence: Hassan II University of Casablanca, 20000 Casablanca, Morocco (ouail.ouchetto@etude.univcasa.ma).

\begin{abstract}
Background: Lethality rates of COVID-19 are so different between countries and continents. This lethality seems to be very low in Africa and Asia, but exceedingly high in western Europe and North America. Many factors could have a role in this disparity such as comorbidities. Advanced age, obesity, cardiovascular disease, diabetes and cancer were the most frequently cited in the reported COVID-19 data. The main objective was to analyze and evaluate the association between the COVID19 mortality and the mentioned factors in 164 countries.

Methods: The Data of COVID-19 deaths, latitude degrees, population age distribution, cardiovascular diseases, obesity, diabetes and cancer were extracted from different online sources. For the statistical analysis, we used Spearman to measure the correlation coefficient between numbers of deaths and the mentioned factors until June 29, 2020.
\end{abstract}


Results: The correlation between COVID-19 mortality and latitude, high age, obesity, CVD and number of cancer patients per 100,000 is significant at 0.01 level with $r=$ $0.489, r=0.511, r=0.489, r=0.561$ and $r=0.536$ respectively. The correlation between the number of deaths and diabetes is less strong than the previous ones, and the correlation coefficient is $r=0.154$.

Conclusion: The great lethality of COVID-19 in western Europe and North America can be explained in part by the highest of age, cancer and CVD percentage in these regions. It seems also plausible that the increased obesity in the USA and vitamin D deficiency in Europe may contribute to increasing the number of COVID-19 deaths.

Keywords: COVID-19; SARS-CoV-2; Risk Factors; Mortality.

\section{Introduction}

Coronavirus disease 2019 (COVID-19) is an infectious disease caused by severe acute respiratory syndrome coronavirus 2 (SARS-CoV-2), which has spread rapidly through China and the rest of the world. SARS-CoV-2 shares some characteristics with two other coronaviruses: severe acute respiratory syndrome coronavirus (SARS-CoV) appeared in 2003 and Middle East respiratory syndrome (MERS-CoV) appeared in 2012. COVID-19 had affected over 10 million people and killed more than 500,000 in over 200 countries worldwide as of 29 June 2020 $[1,2]$. According to the clinical data, some patients with COVID-19 developed acute respiratory distress syndrome and part of them worsened in a short period and died of multiple organ failure.

Researchers have emphasized that patients at risk for severe acute respiratory syndrome coronavirus- 2 have been characterized as having advanced age or preexisting diseases, like obesity, cardiovascular disease, diabetes, cancer or 
chronic respiratory disease (A1). In [3], the presented data support that diabetes should be considered as a risk factor for a rapid progression and bad prognosis of COVID-19 and in case of rapid deterioration, more intensive attention should be paid to diabetic patients. In addition, data from Italy showed more than two-thirds of those who died by severe acute respiratory syndrome coronavirus 2 (SARS-CoV-2) had diabetes [4]. Since obesity has been shown to increase vulnerability to infections, it may be a risk factor for COVID $\square 19 \square$ related mortality [5]. The Seattle region was among the first to report body mass index (BMI) data, and a sample has showed that $85 \%$ of patients with obesity required mechanical ventilation and $62 \%$ of patients with obesity died. These proportions are greater than those in patients without obesity, in which $64 \%$ required mechanical ventilation and $36 \%$ died [6]. Cardiovascular disease is mentioned as one of the most common comorbidities. In Chinese report from 138 hospitalized COVID $\square 19$ patients, $14.5 \%$ had cardiovascular disease [7]. Another study on 99 hospitalized patients in China showed that $40 \%$ of the cohort had cardiovascular or cerebrovascular disease [8]. Cancer can be also a risk factor of COVID-19. In fact, a study of small sample size of SARS-CoV-2 patients reported a higher risk of severe events in patients with cancer when compared with patients without cancer [9]. A multicenter study including 105 patients with cancer and 536 noncancer patients infected with COVID-19 confirmed also that the COVID-19 patients with cancer had higher risks in all severe outcomes. Patients with hematologic cancer, lung cancer, or with metastatic cancer (stage IV) had the highest frequency of severe events [10].

The lethality rates of COVID-19 are very different between countries and continents. This lethality seems to be very low in Africa, Asia and in some South America countries, and high in western Europe and North America. In this work, we 
analyze and evaluate the association between the deaths number of COVID-19 and of the mentioned risk factors in 164 countries.

\section{Method}

The Data of COVID-19 of the studied countries were mainly obtained from Worldometers [1] and European Centre for Disease Prevention and Control [2], as of 29 June 2020. The percentage of obese adults were gathered from the procon.org organization [11] and the percentage of the diabetic population aged between 20 to 79 years were collected from the Index Mundi database [12]. In the other side, the standardized incidence rates of all cancers (per 100,000) were obtained from the Global cancer observatory [13] and the percentages of cardiovascular diseases were extracted from the Global Health Data Exchange (GHDx) database [14]. Finally, the percentage of the population having more than 55 years and latitude degrees are available from $[15,16]$.

This study involves 164 countries around the world. Indeed, we have included all countries whose data on COVID-19 mortality, population age distribution, CVD, obesity, diabetes and cancer are available (see Appendix). As the data were not normally distributed, we used the Spearman test for correlation analysis between the numbers of deaths of COVID-19 per 1 million population in the studied countries and the mentioned factors. Spearman's correlation assesses monotonic relationships whether linear or not [17], and it doesn't depend on the sample sizes and distributions of the variables. The Spearman's correlation between two variables is low when observations have a dissimilar rank between the two variables, and high when observations have a similar rank between the two variables. In the case of no 
repeated data values, a perfect correlation of +1 or -1 is obtained when each of the variables is a perfect monotone function of the other.

\section{Results}

Fig. 1 (a) represents the COVID-19 mortality per million as a function of the latitude degrees. It can be seen that all countries that locate below 35 degrees North have relatively low mortality and they have low than 300 deaths per million population. The correlation between mortality and latitude is $r=0.489$ (see Table 1 ). The distribution of COVID-19 mortality versus high age (55 years and over) is plotted in Fig. 1 (b). The number of deaths correlates positively and significantly with high age $(r=0.511)$. Indeed, the countries with a high number of aged people have the highest deaths number.

Except for Australia and New Zealand, the countries with a high number of cancer patients have the highest deaths number (Fig. 1(c)). The correlation is positive between the number of deaths and number of cancer patients per 100,000 $(r=0.591)$. In the other side, the association between the deaths number and CVD percentage is strong and the correlation coefficient is $r=0,56$ (at 0.01 level). The distribution of CVD is presented in (Fig. 1(d)).

Fig. 1 (e) and Fig. 1 (g) represent the number of deaths versus the percentage of obesity and diabetes, respectively. The association between obesity and the number of deaths is significant with $r=0.489$. However, the association between diabetes and the number of deaths is less strong than the previous ones with $r=$ 0,154 .

\section{Discussion}


The lethality rates of COVID-19 are very different between countries and continents. This lethality seems to be high in western Europe and North America compared to others countries. This North-South difference may be due to several factors. Firstly, the correlation between the number of mortality and latitude degrees can be explained by the vitamin $\mathrm{D}$ deficiency, which associated with increased risk and greater severity of COVID-19 [18]. Indeed, thirty-five degrees North also happens to be the latitude above which people do not receive sufficient sunlight to maintain adequate vitamin $D$ levels during winter. In Europe, the prevalence of hypovitaminosis $D$ is high, but it is relatively uncommon in Nordic countries, probably due to the widespread use of supplements [19], which can explain that the mortality is relatively low in these countries. This correlation can be also explained by the existing of the high prevalence of the elderly population in western Europe and North America. Older people are more likely to develop risk factors and severe health consequences from COVID-19 [20].

Secondly, the percentage of CVD is high in western Europe and North of America, which explains the significant association between mortality and the percentage of CVD. Indeed, CVD patients are more likely to be infected due to their deteriorated heart function. In fact, pre-existing CVD heightens the vulnerability to develop COVID-19 and to have more severe disease with worse clinical outcomes and prognosis [21].

The incidence rate of all cancers remains also high in western Europe and North of America, which provides a significant correlation with the mortality rate. Cancer patients are at high risk for infections due to coexisting chronic diseases, overall weakened health status, and systemic immunosuppressive states caused by both cancer and anticancer treatments [22]. As a consequence, cancer patients 
infected by the SARS-CoV-2 coronavirus may experience more difficult outcomes than other populations.

The correlation between the mortality of COVID-19 and obesity was significant. Even if the obesity prevalence in Europe is not the highest in the world, but it remains high in the North of America. In fact, obesity is characterized by chronic inflammation associated with a decreased immune system, leading to susceptibility to infection [23]. Additionally, patients with obesity show a restrictive breathing pattern and reduced lung volume. This evidence suggests that obesity might act as an independent risk factor for a poor disease progression of COVID-19.

Diabetes mellitus is one of the most common chronic diseases and one of the leading causes of morbidity worldwide [24]. Several studies have demonstrated that diabetics have high susceptibility to some infectious diseases, like Mycobacterium tuberculosis and Staphylococcus aureus [25]. However, the correlation between diabetes and mortality is not significant and this is due to the lowest of prevalence of diabetes in western Europe and north America countries.

\section{Conclusion}

The computed correlation coefficients between the risk factors and the mortality numbers of COVID-19 show that the great lethality of COVID-19 in western Europe and North America can be explained in part by the highest of age, cancer and CVD prevalence in these regions. It seems also plausible that the increased obesity in the USA and vitamin D deficiency in Europe may contribute to increasing the number of COVID-19 deaths. In the other side, the correlation between diabetes and the number of COVID-19 deaths is not very significant.

\section{Acknowledgments. None.}


Funding Source: This work did not receive any funding.

Conflict of Interest: We declare no conflict of interest.

Ethical Approval. Approval was not required

\section{References}

1. Covid-19 Coronavirus Pandemic - 29 June 2020. https://www.worldometers.info/coronavirus/

2. European Centre for Disease Prevention and Control - 29 June 2020. https://www.ecdc.europa.eu/en/publications-data.

3. Guo W, Li M, Dong Y, Zhou H, Zhang Z, Tian C, et al. Diabetes is a risk factor for the progression and prognosis of COVID $\square$ 19. Diabetes-Metab Res, 2020;e3319. https://doi.org/10.1002/dmrr.3319

4. Remuzzi A, Remuzzi G. COVID-19 and Italy: what next? The Lancet 2020. doi: https://doi.org/10.1016/S0140-6736(20)30627-9.

5. Kassir R. Risk of COVID $\square 19$ for patients with obesity. Obesity Reviews, 2020;21(6). 10.1111/obr.13034

6. Bhatraju P K., Ghassemieh B J, Nichols M, Kim R, Jerome KR, Nalla AK, et al. Covid-19 in critically ill patients in the Seattle region-case series. N Engl J Med, 2020;382(21):2012-2022.

7. Wang D, Hu B, Hu C, Zhu F, Liu X, Zhang J, Wang B, Xiang H, Cheng Z, Xiong Y. Clinical characteristics of 138 hospitalized patients with 2019 novel coronavirus-infected pneumonia in Wuhan, China. JAMA. 2020;323(11):10611069. DOI: 10.1001/jama.2020.1585.

8. Chen N, Zhou M, Dong X, Qu J, Gong F, Han Y, Qiu Y, Wang J, Liu Y, Wei Y, et al. Epidemiological and clinical characteristics of 99 cases of 2019 novel coronavirus pneumonia in Wuhan, China: a descriptive study. Lancet. 2020;395:507-513.

9. Liang W, Guan W, Chen R, Wang W, Li J, Xu K, et al. Cancer patients in SARS-CoV-2 infection: a nationwide analysis in China. Lancet Oncol 2020;21:335-37. 
10. Dai M, Liu D, Liu M, Zhou F, Li G, Chen Z, et al. Patients with cancer appear more vulnerable to SARS-COV-2: a multicenter study during the COVID-19 outbreak. Cancer discovery, $2020 ; 10(6): 783-791$.

11. Global Obesity Levels - 25 June 2020. https://obesity.procon.org/globalobesity-levels/

12. Diabetes Prevalence (\% of population ages 20 to 79) - Country Ranking - 25 June

2020. https://www.indexmundi.com/facts/indicators/SH.STA.DIAB.ZS/rankings

13. Global cancer observatory: cancer today. International Agency for Research on Cancer, Lyon, France2018 - 25 June 2020. https://gco.iarc.fr/today.

14. Global Health Data Exchange - 15 June 2020. http://ghdx.healthdata.org/gbdresults-tool.

15. Central Intelligence Agency - 25 June 2020. https://www.cia.gov/library/publications/the-world-factbook/fields/341.html.

16.Google DataSet Publishing Language - 25 June 2020. https://developers.google.com/public-data/docs/canonical/countries_csv

17.Glasser, G.J., Winter, R.F.: Critical values of the coefficient of rank correlation for testing the hypothesis of independance. Biometrika1961;48:444-448.

18. Rhodes JM, Subramanian S, Laird E, Kenny RA. low population mortality from COVID $\square 19$ in countries south of latitude 35 degrees North supports vitamin D as a factor determining severity. Aliment Pharmacol Ther, 2020;51(12):14341437.

19. Lips P, Cashman KD, Lamberg-Allardt C, et al. Current vitamin D status in European and Middle East countries and strategies to prevent vitamin D deficiency: a position statement of the European Calcified Tissue Society. Eur J Endocrinol. 2019;180:23-54.

20. Matsushita K, Ding N, Kou M, Hu X, Chen M, Gao Y, et al. The relationship of COVID-19 severity with cardiovascular disease and its traditional risk factors: A systematic review and meta-analysis. medRxiv. 2020:20054155 https://doi. org/10.1101/2020.04.05.20054155

21. Li B, Yang J, Zhao F, et al. Prevalence and impact of cardiovascular metabolic diseases on COVID-19 in China. Clin Res Cardiol 2020. doi: https://doi.org/10.1007/s00392-020-01626-9. 
22. Chen W, Zheng R, Baade PD, Zhang S, Zeng H, Bray F, et al. Cancer statistics in China, 2015. CA Cancer J Clin 2016;66:115-32.

23. Hegde V, Dhurandhar NV. Microbes and obesity-interrelationship between infection, adipose tissue and the immune system. Clin Microbiol Infect 2013;19:314e20.

24. Knapp S. Diabetes and infection: is there a link?-a mini-review. Gerontology. 2013;59(2):99-104.

25. Muller LM, Gorter KJ, Hak E, et al. Increased risk of common infections in patients with type 1 and type 2 diabetes mellitus. Clin Infect Dis. 2005;41(3):281-288.

Figure 1: Association between COVID-19 mortality per million by country as a function of latitude, percentage of high age (55 years and over), number of cancer patients per 100,000 , percentage of cardiovascular diseases, percentage of obesity and percentage of diabetes. 
medRxiv preprint doi: https://doi.org/10.1101/2020.07.02.20145375; this version posted July 7, 2020. The copyright holder for this preprint (which was not certified by peer review) is the author/funder, who has granted medRxiv a license to display the preprint in perpetuity.

It is made available under a CC-BY 4.0 International license .

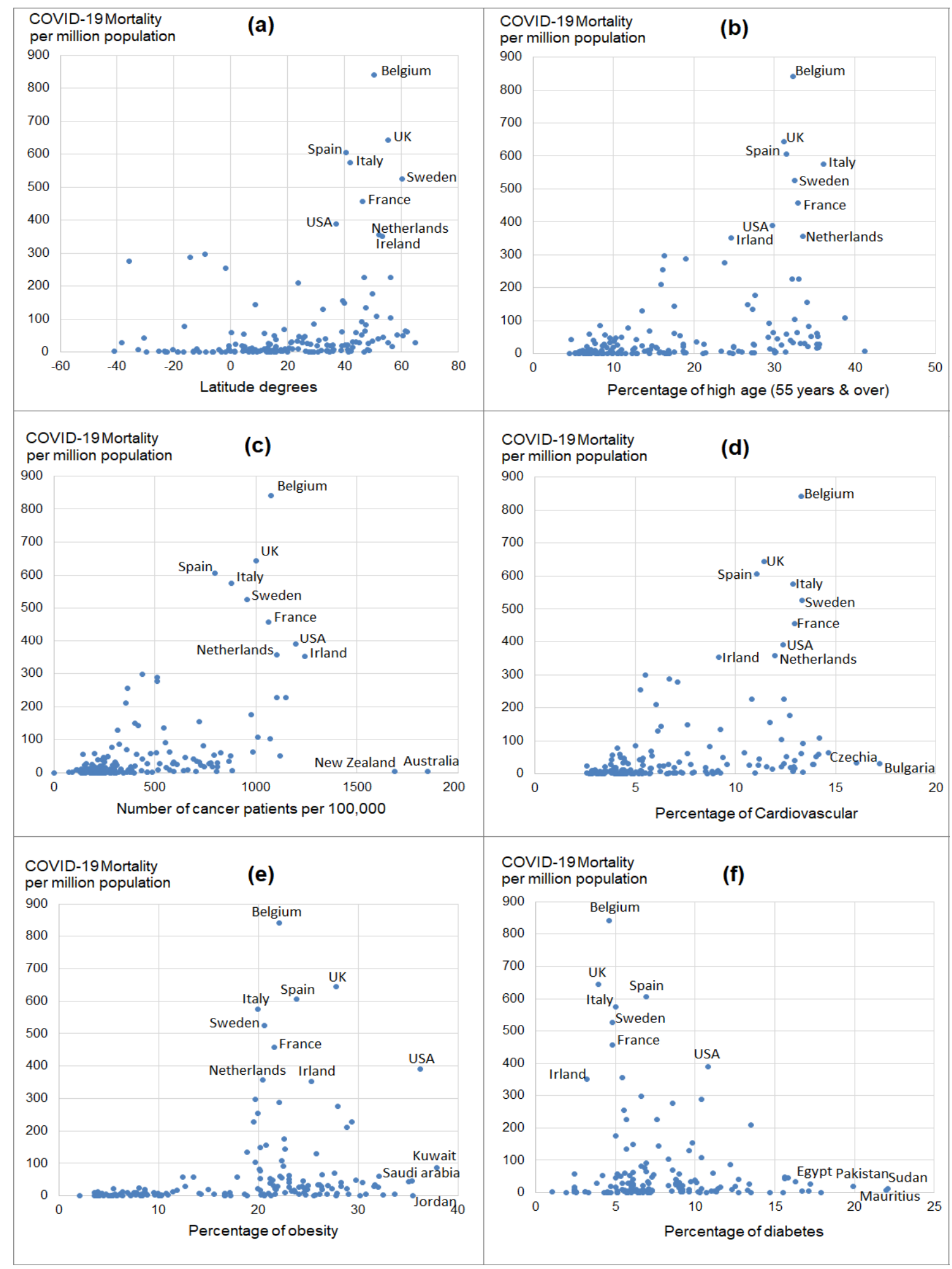

\section{Table1: Correlation coefficients between COVID-19 mortality and high age, obesity, diabetes, cardiovascular diseases (CVD) and cancer.}




\begin{tabular}{|c|c|c|c|c|c|c|c|}
\hline \multicolumn{8}{|c|}{ Correlations } \\
\hline & & Latitude & $\begin{array}{l}\text { Age }(55 \\
\text { years } \\
\text { \& over) }\end{array}$ & Diabetes & Obesity & $\begin{array}{c}\text { Cardiovascu } \\
\text { lar } \\
\text { Diseases }\end{array}$ & $\begin{array}{c}\text { Cance } \\
\mathbf{r}\end{array}$ \\
\hline \multirow{3}{*}{$\begin{array}{l}\text { Mortality } \\
\text { per } \\
\text { million }\end{array}$} & $\begin{array}{l}\text { Correlation } \\
\text { Coefficient }\end{array}$ & $0.489^{* *}$ & $0.511^{* *}$ & $0.154^{*}$ & $0.489^{* *}$ & $0.561^{* *}$ & $0.536^{\star *}$ \\
\hline & \begin{tabular}{|l} 
Sig. $(2-$ \\
tailed) \\
\end{tabular} & 0.000 & 0.000 & 0.048 & 0.000 & 0.000 & 0.000 \\
\hline & $\mathrm{N}$ & 164 & 164 & 164 & 164 & 164 & 164 \\
\hline \multicolumn{8}{|c|}{${ }^{* *}$. Correlation is significant at the 0.01 level (2-tailed). } \\
\hline \multicolumn{8}{|c|}{ *. Correlation is significant at the 0.05 level (2-tailed). } \\
\hline
\end{tabular}

\section{Appendix}

Table: Worldwide mortality rate of COVID-19, latitude degrees, percentage of age (55 years and over), obesity, diabetes, cardiovascular disease (CVD) and cancer (per 100,000).

\begin{tabular}{|l|r|r|r|r|r|r|r|}
\hline Country & $\begin{array}{l}\text { Deaths/ } \\
\text { 1 } \begin{array}{l}\text { Million } \\
\text { population }\end{array}\end{array}$ & $\begin{array}{l}\text { Latitude } \\
\text { Degrees }\end{array}$ & $\begin{array}{l}\text { Cancer/ } \\
(\mathbf{1 0 0 . 0 0 0})\end{array}$ & $\begin{array}{l}\text { Diabetes } \\
(\%)\end{array}$ & $\begin{array}{l}\text { Obesity } \\
(\%)\end{array}$ & $\begin{array}{l}\text { CVD } \\
\text { (\%) }\end{array}$ & $\begin{array}{l}\text { Age 55 } \\
\text { years \& } \\
\text { over (\%) }\end{array}$ \\
\hline Belgium & 841 & 50.50 & 1076 & 4.6 & 22.1 & 13.27 & 32.35 \\
\hline UK & 644 & 55.38 & 1001.9 & 3.9 & 27.8 & 11.42 & 31.21 \\
\hline Spain & 606 & 40.46 & 798.2 & 6.9 & 23.8 & 11.06 & 31.48 \\
\hline Italy & 575 & 41.87 & 878.4 & 5 & 19.9 & 12.87 & 36.08 \\
\hline Sweden & 526 & 60.13 & 956.8 & 4.8 & 20.6 & 13.33 & 32.49 \\
\hline France & 457 & 46.23 & 1060.7 & 4.8 & 21.6 & 12.95 & 32.93 \\
\hline United States & 390 & 37.09 & 1195.7 & 10.8 & 36.2 & 12.37 & 29.71 \\
\hline Netherlands & 357 & 52.13 & 1103.4 & 5.4 & 20.4 & 11.99 & 33.51 \\
\hline Ireland & 352 & 53.41 & 1240.5 & 3.2 & 25.3 & 9.18 & 24.59 \\
\hline Chile & 298 & -35.68 & 512.1 & 8.6 & 28 & 7.11 & 23.79 \\
\hline Peru & 288 & -9.19 & 438.8 & 6.6 & 19.7 & 5.52 & 16.33 \\
\hline Brazil & 277 & -14.24 & 513.3 & 10.4 & 22.1 & 6.7 & 18.99 \\
\hline Ecuador & 255 & -1.83 & 362.9 & 5.5 & 19.9 & 5.25 & 16.07 \\
\hline Canada & 227 & 56.13 & 1148.3 & 7.6 & 29.4 & 12.44 & 33.06 \\
\hline Switzerland & 227 & 46.82 & 1102.9 & 5.7 & 19.5 & 10.83 & 32.21 \\
\hline Mexico & 210 & 23.63 & 354.2 & 13.5 & 28.9 & 6.03 & 15.96 \\
\hline
\end{tabular}


medRxiv preprint doi: https://doi.org/10.1101/2020.07.02.20145375; this version posted July 7, 2020. The copyright holder for this preprint (which was not certified by peer review) is the author/funder, who has granted medRxiv a license to display the preprint in perpetuity.

It is made available under a CC-BY 4.0 International license.

\begin{tabular}{|c|c|c|c|c|c|c|c|}
\hline Luxembourg & 176 & 49.82 & 975.6 & 5 & 22.6 & 12.73 & 27.56 \\
\hline Portugal & 155 & 39.40 & 719.2 & 9.8 & 20.8 & 11.74 & 34 \\
\hline Armenia & 149 & 40.07 & 402.2 & 6.1 & 20.2 & 7.62 & 26.68 \\
\hline Panama & 144 & 8.54 & 418.3 & 7.7 & 22.7 & 6.29 & 17.55 \\
\hline Moldova & 135 & 47.41 & 545.5 & 5.7 & 18.9 & 9.25 & 27.29 \\
\hline Iran & 129 & 32.43 & 314.2 & 9.6 & 25.8 & 6.15 & 13.59 \\
\hline Germany & 108 & 51.17 & 1010.9 & 10.4 & 22.3 & 14.21 & 38.73 \\
\hline Denmark & 104 & 56.26 & 1068.9 & 8.3 & 19.7 & 12.29 & 32.54 \\
\hline Bolivia & 92 & -16.29 & 285.4 & 6.8 & 20.2 & 4.13 & 11.77 \\
\hline Romania & 86 & 45.94 & 552.6 & 6.9 & 22.5 & 13.37 & 29.31 \\
\hline Kuwait & 83 & 29.31 & 321.8 & 12.2 & 37.9 & 5.01 & 8.35 \\
\hline Austria & 78 & 47.52 & 737.9 & 6.6 & 20.1 & 8.73 & 34.28 \\
\hline $\begin{array}{l}\text { Dominican } \\
\text { Republic }\end{array}$ & 69 & 18.74 & 361.5 & 8.6 & 27.6 & 5.82 & 14.46 \\
\hline Russia & 64 & 61.52 & 571.3 & 6.1 & 23.1 & 10.46 & 29.84 \\
\hline Colombia & 63 & 4.57 & 407.8 & 7.4 & 22.3 & 5.84 & 18.32 \\
\hline Hungary & 61 & 47.16 & 984 & 6.9 & 26.4 & 14.63 & 32.86 \\
\hline Turkey & 61 & 38.96 & 508.3 & 11.1 & 32.1 & 7.63 & 17.6 \\
\hline Finland & 59 & 61.92 & 825.6 & 5.6 & 22.2 & 13.28 & 35.28 \\
\hline Sao Tome & 59 & 0.19 & 199.2 & 2.4 & 12.4 & 4.23 & 7.04 \\
\hline $\begin{array}{l}\text { Bosnia \& } \\
\text { Herzegovina }\end{array}$ & 57 & 43.92 & 479.2 & 9 & 17.9 & 14.17 & 31.46 \\
\hline Djibouti & 55 & 11.83 & 143.7 & 5.1 & 13.5 & 3.87 & 8.98 \\
\hline Slovenia & 53 & 46.15 & 875.6 & 5.9 & 20.2 & 14.01 & 35.42 \\
\hline Estonia & 52 & 58.60 & 794.8 & 4.2 & 21.2 & 12.54 & 34.58 \\
\hline Bahrain & 51 & 25.93 & 265.9 & 15.6 & 29.8 & 5.39 & 10.25 \\
\hline Honduras & 49 & 15.20 & 264.7 & 7.3 & 21.4 & 4.27 & 10.98 \\
\hline Iraq & 48 & 33.22 & 219.1 & 8.8 & 30.4 & 5.34 & 7.56 \\
\hline Saudi Arabia & 47 & 23.89 & 246.3 & 15.8 & 35.4 & 4.45 & 9.58 \\
\hline Norway & 46 & 60.47 & 1120.3 & 5.3 & 23.1 & 9.39 & 29.27 \\
\hline South Africa & 43 & -30.56 & 436.2 & 12.7 & 28.3 & 5.21 & 12.89 \\
\hline Guatemala & 42 & 15.78 & 238.9 & 10 & 21.2 & 4.47 & 10.11 \\
\hline Belarus & 41 & 53.71 & 649 & 5 & 24.5 & 11.18 & 30.38 \\
\hline Qatar & 40 & 25.35 & 250.3 & 15.6 & 35.1 & 3.82 & 4.72 \\
\hline Poland & 39 & 51.92 & 691.5 & 6.1 & 23.1 & 12.96 & 32.04 \\
\hline Israel & 35 & 31.05 & 706.4 & 9.7 & 26.1 & 7.19 & 20.36 \\
\hline Oman & 34 & 21.51 & 250 & 10.1 & 27 & 4.64 & 7.7 \\
\hline Czechia & 33 & 49.82 & 868.2 & 7 & 26 & 16.03 & 32.35 \\
\hline Bulgaria & 32 & 42.73 & 591.8 & 6 & 25 & 17.2 & 33.21 \\
\hline Serbia & 32 & 44.02 & 721.2 & 9 & 21.5 & 12.43 & 33.7 \\
\hline UAE & 32 & 23.42 & 303.1 & 16.3 & 31.7 & 4.39 & 9.58 \\
\hline
\end{tabular}


medRxiv preprint doi: https://doi.org/10.1101/2020.07.02.20145375; this version posted July 7, 2020. The copyright holder for this preprint (which was not certified by peer review) is the author/funder, who has granted medRxiv a license to display the preprint in perpetuity.

It is made available under a CC-BY 4.0 International license.

\begin{tabular}{|c|c|c|c|c|c|c|c|}
\hline Iceland & 29 & 64.96 & 810.8 & 5.8 & 21.9 & 9.58 & 27.41 \\
\hline Lithuania & 29 & 55.17 & 775.5 & 3.8 & 26.3 & 13.87 & 35.55 \\
\hline Argentina & 28 & -38.42 & 587.1 & 5.9 & 28.3 & 7.76 & 21.2 \\
\hline Bahamas & 28 & 25.03 & 462.5 & 8.8 & 31.6 & 6.65 & 18.71 \\
\hline Egypt & 28 & 26.82 & 308.3 & 17.2 & 32 & 5.37 & 10.52 \\
\hline Mauritania & 28 & 21.01 & 161.8 & 7.1 & 12.7 & 3.77 & 8.82 \\
\hline El Salvador & 27 & 13.79 & 290.3 & 8.8 & 24.6 & 6.22 & 14.83 \\
\hline Ukraine & 27 & 48.38 & 524.5 & 6.1 & 24.1 & 11.13 & 30.9 \\
\hline Croatia & 26 & 45.10 & 769.8 & 5.4 & 24.4 & 13.92 & 35.3 \\
\hline Cape Verde & 25 & 16.00 & 254.2 & 2.4 & 11.8 & 5.81 & 12.6 \\
\hline Barbados & 24 & 13.19 & 607.9 & 13.4 & 23.1 & 10.7 & 27.48 \\
\hline Equatorial Guinea & 23 & 1.65 & 189.2 & 6 & 8 & 2.6 & 8.61 \\
\hline Albania & 22 & 41.15 & 401.1 & 9 & 21.7 & 12.31 & 24.97 \\
\hline Suriname & 22 & 3.92 & 381 & 12.5 & 26.4 & 6.95 & 15.33 \\
\hline Algeria & 21 & 28.03 & 312.6 & 6.7 & 27.4 & 6.4 & 13.58 \\
\hline Azerbaijan & 21 & 40.14 & 228.1 & 6.1 & 19.9 & 12.91 & 18.7 \\
\hline Malta & 20 & 35.94 & 729.5 & 8.3 & 28.9 & 11.57 & 34.18 \\
\hline Afghanistan & 19 & 33.94 & 151 & 9.2 & 5.5 & 3.48 & 6.69 \\
\hline Gabon & 19 & -0.80 & 238.4 & 6 & 15 & 4.05 & 9.17 \\
\hline Montenegro & 19 & 42.71 & 555.6 & 9 & 23.3 & 11.84 & 29.43 \\
\hline Pakistan & 19 & 30.38 & 200.3 & 19.9 & 8.6 & 3.94 & 9.99 \\
\hline Greece & 18 & 39.07 & 783.8 & 4.7 & 24.9 & 12.77 & 35.53 \\
\hline Cyprus & 16 & 35.13 & 743.2 & 9 & 21.8 & 8.51 & 24.89 \\
\hline Latvia & 16 & 56.88 & 808.6 & 5 & 23.6 & 12.94 & 35.27 \\
\hline Guyana & 15 & 4.86 & 219.4 & 11.6 & 20.2 & 5.75 & 15.38 \\
\hline India & 13 & 20.59 & 173.5 & 10.4 & 3.9 & 4.37 & 14.63 \\
\hline Sudan & 13 & 12.86 & 158.4 & 22.1 & 8.6 & 4.05 & 7.16 \\
\hline Cameroon & 12 & 7.37 & 180.5 & 6 & 11.4 & 3.02 & 6.98 \\
\hline Guinea-Bissau & 12 & 11.80 & 135.5 & 2.4 & 9.5 & 2.83 & 6.2 \\
\hline Philippines & 12 & 12.88 & 330.3 & 7.1 & 6.4 & 4.44 & 11.04 \\
\hline Bangladesh & 11 & 23.68 & 168.3 & 9.2 & 3.6 & 5.29 & 14.23 \\
\hline Indonesia & 11 & -0.79 & 298 & 6.3 & 6.9 & 5.25 & 16.81 \\
\hline Nicaragua & 11 & 12.87 & 277.5 & 11.4 & 23.7 & 4.78 & 12.45 \\
\hline $\begin{array}{l}\text { Central African } \\
\text { Republic }\end{array}$ & 10 & 6.61 & 110.8 & 6 & 7.5 & 2.93 & 7.67 \\
\hline Kazakhstan & 10 & 48.02 & 384.4 & 6.1 & 21 & 6.27 & 18.68 \\
\hline Yemen & 10 & 15.55 & 115.4 & 5.4 & 17.1 & 3.77 & 6.8 \\
\hline Haiti & 9 & 18.97 & 207.3 & 6.7 & 22.7 & 4.3 & 9.63 \\
\hline Kyrgyzstan & 9 & 41.20 & 237.9 & 6.1 & 16.6 & 4.65 & 13.89 \\
\hline Comoros & 8 & -11.88 & 166.3 & 12.3 & 7.8 & 4.4 & 8.57 \\
\hline Cuba & 8 & 21.52 & 516.8 & 9.6 & 24.6 & 9.12 & 29.91 \\
\hline
\end{tabular}


medRxiv preprint doi: https://doi.org/10.1101/2020.07.02.20145375; this version posted July 7, 2020. The copyright holder for this preprint (which was not certified by peer review) is the author/funder, who has granted medRxiv a license to display the preprint in perpetuity.

It is made available under a CC-BY 4.0 International license.

\begin{tabular}{|c|c|c|c|c|c|c|c|}
\hline Japan & 8 & 36.20 & 662.4 & 5.6 & 4.3 & 12.88 & 41.24 \\
\hline Mauritius & 8 & -20.35 & 367.6 & 22 & 10.8 & 8.53 & 23.39 \\
\hline Sierra Leone & 8 & 8.46 & 141 & 2.4 & 8.7 & 3.56 & 7.59 \\
\hline Uruguay & 8 & -32.52 & 643.2 & 7.3 & 27.9 & 8.84 & 25.5 \\
\hline Brunei & 7 & 4.54 & 572.2 & 13.3 & 14.1 & 4.39 & 14.24 \\
\hline Congo democratic & 7 & -4.04 & 153 & 6 & 9.6 & 3.47 & 5.83 \\
\hline Liberia & 7 & 6.43 & 142.9 & 2.4 & 9.9 & 3.24 & 6.29 \\
\hline Senegal & 7 & 14.50 & 189.5 & 2.4 & 8.8 & 3.52 & 7.31 \\
\hline Mali & 6 & 17.57 & 202.3 & 2.4 & 8.6 & 2.9 & 6.7 \\
\hline Morocco & 6 & 31.79 & 288.9 & 7 & 26.1 & 7.29 & 15.78 \\
\hline Somalia & 6 & 5.15 & 148.8 & 5.1 & 8.3 & 3.04 & 6.88 \\
\hline South Korea & 6 & 35.91 & 880.7 & 6.9 & 4.7 & 7.93 & 31.39 \\
\hline Trinidad \& Tobago & 6 & 10.69 & 432.1 & 11 & 18.6 & 9.05 & 25.94 \\
\hline Belize & 5 & 17.19 & 274.9 & 17.1 & 24.1 & 5 & 10.71 \\
\hline Chad & 5 & 15.45 & 128.9 & 6 & 6.1 & 2.81 & 5.67 \\
\hline Lebanon & 5 & 33.85 & 593.7 & 11.2 & 33.7 & 5.08 & 17.58 \\
\hline Slovakia & 5 & 48.67 & 803.3 & 6.5 & 20.5 & 13.38 & 30.2 \\
\hline Tajikistan & 5 & 38.86 & 149.6 & 6.1 & 14.2 & 3.8 & 9.86 \\
\hline Australia & 4 & -25.27 & 1849.8 & 5.6 & 29 & 9.27 & 27.23 \\
\hline Georgia & 4 & 42.32 & 329.7 & 5.8 & 21.7 & 11 & 30.09 \\
\hline Ghana & 4 & 7.95 & 228.5 & 2.5 & 10.9 & 3.81 & 9.65 \\
\hline Malaysia & 4 & 4.21 & 337.2 & 16.7 & 15.6 & 6.99 & 15.71 \\
\hline New Zealand & 4 & -40.90 & 1686.8 & 6.2 & 30.8 & 8.94 & 27.47 \\
\hline Singapore & 4 & 1.35 & 703 & 5.5 & 6.1 & 6.91 & 21.47 \\
\hline Tunisia & 4 & 33.89 & 256.1 & 8.5 & 26.9 & 7.35 & 18.98 \\
\hline Burkina Faso & 3 & 12.24 & 158.1 & 7.3 & 5.6 & 2.95 & 6.73 \\
\hline China & 3 & 35.86 & 377.6 & 9.2 & 6.2 & 7.86 & 24.42 \\
\hline Costa Rica & 3 & 9.75 & 487.4 & 9.1 & 25.7 & 6.7 & 18.75 \\
\hline Ivory Coast & 3 & 7.54 & 166.9 & 2.4 & 10.3 & 3.25 & 6.38 \\
\hline Jamaica & 3 & 18.11 & 461.8 & 11.3 & 24.7 & 7.02 & 18.8 \\
\hline Kenya & 3 & -0.02 & 302.4 & 3.1 & 7.1 & 3.42 & 7.08 \\
\hline Libya & 3 & 26.34 & 254 & 10.2 & 32.5 & 5.74 & 9.56 \\
\hline Niger & 3 & 17.61 & 89.1 & 2.4 & 5.5 & 2.58 & 5.85 \\
\hline Nigeria & 3 & 9.08 & 183.2 & 3.1 & 8.9 & 2.98 & 7.43 \\
\hline Benin & 2 & 9.31 & 198.1 & 1 & 9.6 & 2.92 & 5.54 \\
\hline Guinea & 2 & 9.95 & 131 & 2.4 & 7.7 & 3.3 & 8.64 \\
\hline Paraguay & 2 & -23.44 & 385.4 & 9.6 & 20.3 & 5.53 & 16.25 \\
\hline Togo & 2 & 8.62 & 169.7 & 2.4 & 8.4 & 3.39 & 7.99 \\
\hline Venezuela & 2 & 6.42 & 461.1 & 7 & 25.6 & 4.81 & 16.94 \\
\hline Nepal & 1 & 28.39 & 171.5 & 7.2 & 4.1 & 4.46 & 12.33 \\
\hline Zambia & 1 & -13.13 & 266.9 & 4.5 & 8.1 & 2.9 & 5.28 \\
\hline
\end{tabular}


medRxiv preprint doi: https://doi.org/10.1101/2020.07.02.20145375; this version posted July 7, 2020. The copyright holder for this preprint (which was not certified by peer review) is the author/funder, who has granted medRxiv a license to display the preprint in perpetuity.

It is made available under a CC-BY 4.0 International license.

\begin{tabular}{|c|c|c|c|c|c|c|c|}
\hline Ethiopia & 0.9 & 9.15 & 155.7 & 4.3 & 4.5 & 2.85 & 7.8 \\
\hline Jordan & 0.9 & 30.59 & 358.6 & 12.7 & 35.5 & 4.58 & 8.78 \\
\hline Gambia & 0.8 & 13.44 & 74.8 & 1.9 & 10.3 & 3.34 & 8.09 \\
\hline Thailand & 0.8 & 15.87 & 318.6 & 7 & 10 & 8.88 & 24.83 \\
\hline Madagascar & 0.7 & -18.77 & 194.8 & 4.5 & 5.3 & 3.35 & 8.07 \\
\hline Malawi & 0.7 & -13.25 & 277.7 & 4.5 & 5.8 & 3.47 & 5.66 \\
\hline Uzbekistan & 0.7 & 41.38 & 182.4 & 6.5 & 16.6 & 4.94 & 14.5 \\
\hline Sri Lanka & 0.5 & 7.87 & 214.4 & 10.7 & 5.2 & 6.63 & 21.11 \\
\hline Syria & 0.5 & 34.80 & 298.5 & 13.5 & 27.8 & 5.72 & 9.87 \\
\hline Zimbabwe & 0.5 & 29.15 & 1.8 & 15.5 & 3.59 & 8.59 & 4.52 \\
\hline Botswana & 0.4 & -22.33 & 236.7 & 5.8 & 18.9 & 4.35 & 11.48 \\
\hline Tanzania & 0.4 & -6.37 & 229.2 & 5.7 & 8.4 & 3.17 & 6.6 \\
\hline Angola & 0.3 & -11.20 & 190.2 & 4.5 & 8.2 & 2.7 & 5.73 \\
\hline Mozambique & 0.2 & -18.67 & 192.2 & 3.3 & 7.2 & 3.18 & 6.24 \\
\hline Rwanda & 0.2 & -1.94 & 220 & 5.1 & 5.8 & 3.11 & 6.89 \\
\hline Burundi & 0.08 & -3.37 & 194.8 & 5.1 & 5.4 & 3.07 & 7.23 \\
\hline Bhutan & 0 & 27.51 & 137.1 & 10.3 & 6.4 & 3.99 & 12.99 \\
\hline Cambodia & 0 & 12.57 & 198.9 & 6.4 & 3.9 & 4.25 & 11.03 \\
\hline Eritrea & 0 & 15.18 & 142.6 & 5.1 & 5 & 2.85 & 7.8 \\
\hline Fiji & 0 & -16.58 & 395 & 14.7 & 30.2 & 6.57 & 16.59 \\
\hline Lao PDR & 0 & 19.86 & 255.6 & 6.4 & 5.3 & 4.24 & 9.86 \\
\hline Lesotho & 0 & -29.61 & 199.2 & 4.5 & 16.6 & 4.18 & 10.58 \\
\hline Mongolia & 0 & 46.86 & 308.7 & 4.7 & 20.6 & 5.19 & 12.82 \\
\hline Namibia & 0 & -22.96 & 281.7 & 4.5 & 17.2 & 4.08 & 8.58 \\
\hline $\begin{array}{l}\text { Papua New } \\
\text { Guinea }\end{array}$ & 0 & -6.31 & 342.8 & 17.9 & 21.3 & 3.98 & 10.47 \\
\hline Timor-Leste & 0 & -8.87 & 155.2 & 6.7 & 3.8 & 4.19 & 9.28 \\
\hline Uganda & 0 & 1.37 & 247.7 & 2.5 & 5.3 & 2.75 & 5.29 \\
\hline Viet Nam & 0 & 14.06 & 279 & 6 & 2.1 & 5.36 & 16.46 \\
\hline
\end{tabular}

